\title{
THE IMPACT OF REFERENCE GROUPS ON THE PURCHASE INTENTIONS OF SPORTING PRODUCTS: THE CASE FOR SPECTATORSHIP AND PARTICIPATION
}

\author{
Panjarat Pransopon* and Danupol Hoonsopon \\ Department of Marketing, Faculty of Commerce and Accountancy, \\ Chulalongkorn University, Bangkok 10330, Thailand \\ *Corresponding author: Panjarat.Pr@student.chula.ac.th
}

Published online: 27 June 2019

To cite this article: Pransopon, P. and Hoonsopon, D. (2019). The impact of reference groups on purchase intentions of sporting products: The case of spectatorship and participation. Asian Academy of Management Journal, 24(1), 1-23. https://doi. org/10.21315/aamj2019.24.1.1

To link to this article: https://doi.org/10.21315/aamj2019.24.1.1

\begin{abstract}
The purpose of this research is to investigate the impact of reference groups and different types of sports consumers on their purchase intentions for sporting products. Several studies have examined the role of reference groups (private and public) on purchase intentions in the sports marketing area. However, there is a shortage of investigation into the impact of reference groups for each type of sports consumer (spectatorship and participation). Additionally, the effect of strangers on the purchase intentions of sports consumers has been overlooked. After drawing from the social identity theory and conducting experimental research with 593 respondents who have interest in either watching or playing sports, as well as analysing the research with structural equation modelling, the results show that private groups influence the purchase intentions of participation for sporting products. However, public groups and strangers influence the spectatorship purchase intentions of sporting products. This study provides a contribution to the social identity theory by revealing that reference groups provide a diverse effect on purchase intentions for each type of sports consumer.
\end{abstract}

Keywords: social identity theory, sports consumers, spectatorship, participation, purchase intention

(C) Asian Academy of Management and Penerbit Universiti Sains Malaysia, 2019. This work is licensed under the terms of the Creative Commons Attribution (CC BY) (http://creativecommons. org/licenses/by/4.0/). 


\section{INTRODUCTION}

Today, sports marketing plays an important role in related industries such as sports manufacturing, tourism, and healthcare. Sports market revenue has experienced significant growth, from $\$ 46.5$ billion in 2005 to $\$ 90.9$ billion in 2017 (Statista, 2018), which comes from the preference of people worldwide to play and watch sports more than they did in the past. For this reason, firms can use sports marketing as one of their marketing strategies to gain extensive access to new consumer groups. For example, major sports brands not only develop sports shoes for athletes but also introduce fashion and lifestyle footwear for non-sports consumers.

Sports marketing is the adaptation of a marketing strategy and marketing process for use, specifically with sporting products (Mullin, Hardy, \& Sutton, 2000). Scholars (e.g., Filo, Lock, \& Karg, 2015) have tried to explore the marketing factors that affect sports consumers' purchase decisions, such as demographics (Bennett, Ferreira, Lee, \& Polite, 2009), brand equity (Underwood, Bond, \& Baer, 2001; Watkins, 2014), motivators and constraints (Kim \& Trail, 2010), gender of the sports fans (Farrell, Fink, \& Fields, 2011; James \& Ridinger, 2002), and typologies of sports consumers (Stewart, Smith, \& Nicholson, 2003; Sun, Youn, \& Wells, 2004). The reference group is one factor that affects the purchase intentions of sports consumers. In the marketing domain, academicians agree on the importance of reference groups for purchase decisions by consumers (Bearden \& Etzel, 1982; Hoonsopon \& Puriwat, 2016). Many sports scholars adopt the role of reference groups in the decisions to purchase sporting products in several ways, such as the attractiveness of the endorser and product match-up (Tingchi Liu, Huang, \& Minghua, 2007), endorser credibility for sports and non-sports products (Zhou \& Tainsky, 2017), self-esteem enhancement (Swanson, Gwinner, Larson, \& Janda, 2003), and team identification (Bodet \& Bernache-Assollant, 2011; Madrigal, 2000).

Group and social factors have an impact on the attitudes and values of people, and this is reflected in each consumer's buying behaviour (Childers \& Rao, 1992). There is extensive literature (e.g., Bearden \& Etzel, 1982; Childers \& Rao, 1992; Luo, 2005; Tan, 1999) that explores the influence of different types of reference groups on the consumers' purchase intentions. Researchers found that reference groups affect the purchase intentions for each type of consumer (Bearden \& Etzel, 1982; Hoonsopon \& Puriwat, 2016). Consumers often use the reference groups' suggestions to guide their purchase intentions (Luo, 2005; Noguti \& Russell, 2014). For instance, consumers might ask their friends and family before they make a purchase decision. Frequently, consumers make a purchase decision because of the guarantee of a celebrity or an influencer. Sometimes, consumers 
may buy a product/service endorsed by strangers or unknown persons, such as selecting unfamiliar food in a restaurant.

It is not only the reference groups but also the type of consumer that can affect the consumers' purchase intentions. Sports scholars (e.g., Burnett, Menon, \& Smart, 1993; Drayer, Shapiro, Dwyer, Morse, \& White, 2010; Kurpis, Bozman, \& Kahle, 2010; Shoham \& Kahle, 1996; Sun et al., 2004) have classified sports consumers into two types: spectatorship and participation. Spectatorship is explained as consumers attending or watching sports on television or at a stadium (Bennett et al., 2009). In contrast, participation is defined as consumers actually participating in physical sports activities (Allender, Cowburn, \& Foster, 2006). From these definitions, it is implied that the behaviours of each type of sports consumer are not the same. Each type of sports consumer may use different reference groups as a guideline for their sporting goods purchase intentions. Although several studies explore the impact of reference groups on decisions to purchase sporting products, there are some limitations. First, there is a lack of literature investigating the relative effects of the different types of reference groups (private vs. public vs. stranger) on intentions to purchase sporting products. Second, the impact of the type of sports consumer (spectatorship vs. participation) on the sporting product purchase intentions is not explored in detail. These reasons raise questions about how sports consumers respond to reference groups when making sporting product purchase decisions.

The main objective of this research is to examine the impact of reference groups on different types of sports consumers regarding their sporting product purchase intentions. The study divides reference groups into three categories: private (family and friends), public (celebrities and influencers), and strangers. Additionally, two types of sports consumers (spectatorship and participation) are used in this study. We expect that our findings could expand the social identity theory into sports marketing. Moreover, managers can benefit from the results by enhancing their understanding of how sports consumers react to reference groups when they purchase sporting products.

\section{THEORETICAL FOUNDATIONS AND LITERATURE REVIEW}

\section{Social Identity Theory}

Social identity theory has been prevalent in the area of consumer behaviour (Belk, 1988). Belk tried to explain the relationship between possessions and self-identity to better understand the behaviour of consumers. He argued that possessions are 
considered to be a part of ourselves. Van Leeuwen, Quick, and Daniel (2002) concluded that individuals identify with their possessions and that possessions express the individual. Social identity theory is the result of socialisation, changing cultural processes, and education, which are shown in the lifestyles, ideas, beliefs, and behavioural patterns of individuals (Tajfel, 1982). Social identity theory tries to explain the cognition and the behaviour that stems from a group process. Additionally, it assumes that a person knows his group's behaviours and discriminates between other groups. This is a part of the social identity process, and the objective is to gain self-esteem and positive self-enhancement (Abrams \& Hogg, 1988).

Several scholars, such as Filo et al. (2015), Underwood et al. (2001), Van Leeuwen et al. (2002), and Watkins (2014) have adopted social identity theory in the sports marketing domain. The sports industry is highly ranked in terms of consumer commitment and industry identification (Underwood et al., 2001). Underwood et al. (2001) have suggested that sports consumers receive a sense and feeling of identity from their association with a team and athletes. Further, sports consumers also observe the product and tap into that emotional connection, which leads to an enhanced chance of sports consumers buying a product or brand that is identified with a team or a popular athlete. Social media is used to communicate and build relationships between brands and sports consumers (Filo et al., 2015). Sports consumers can interact with brands at various stages of the consumption process, since there is an awareness to act. Sporting products can connect and build images to fit with the identities of sports consumers at each stage of the consumption process. In summary, the idea of social identity helps to explain why sports consumers increase their purchase intentions when the sporting products or brands fit with their identities.

\section{Reference Group}

A reference group is a person or a group of persons who influence the behaviour of other people. People often compare themselves with the group and allow themselves to be guided by the group to improve their attitude, knowledge, and behaviour (Hoyer, MacInnis, \& Pieters, 2001). Sometimes, a consumer's decision can be affected by his reference group (Bearden \& Etzel, 1982; Hoonsopon, 2016).

Many researchers have classified the types of references in different ways. For example, Childers and Rao (1992) use family as a reference group. On the other hand, Tan (1999) defines the reference group in terms of celebrities and experts. Each type of reference group affects people differently. Families and friends affect the norms of people and their attitudes by their interaction (Childers \& Rao, 1992). 
However, celebrities and influencers demonstrate a high standard of success that people follow and prioritise (Childers \& Rao, 1992). For these reasons, if people use different sources of information to make decisions, the effect of reference groups on the purchase intention might vary.

The private group primarily includes parents, other relatives, and friends who often directly interact with the individual (Childers \& Rao, 1992). The public group consists of celebrities, experts, and influencers with whom the individual compares himself or herself (Childers \& Rao, 1992). Strangers are a group of unacquainted people that consumers did not know beforehand (McGrath \& Otnes, 1995). Sometimes, people find that they are pulled into the social exchange of information with other people with whom they are unacquainted (McGrath \& Otnes, 1995). For example, consumers are shopping for badminton rackets and strangers are also shopping in the same store. If strangers make a purchase decision during a consumer's consideration of a racket, consumers may be influenced by the stranger's decision and buy the same racket. Furthermore, Hoonsopon and Puriwat (2016) mention that strangers can affect the consumers' purchase intentions. Therefore, this research explores the impact of these three types of reference groups.

In making the decision to buy, consumers might make a purchase by following the group norms (Noguti \& Russell, 2014; Serralvo, Sastre, \& Joao, 2010; Venkatesan, 1966) or following the celebrities and influencers who support or advertise a product (Bearden, Netemeyer, \& Teel, 1989; Till \& Shimp, 1998). This is because the consumers believe the information that others provide (Luo, 2005). For instance, Kurt, Inman, and Argo (2011) found that men tend to have more purchase intentions when they go shopping with their friends. Therefore, it is expected that reference groups influence the purchase intentions of sports consumers, but these influences vary depending on the type of consumer. The reason is that the attitudes, norms, values, and behaviours of each type of consumer are different, and consumers may use these as different sources of information for making their decision.

\section{Types of Sports Consumers}

Past literature (e.g., Burnett et al., 1993; Sun et al., 2004) has tried to classify the types of sports consumers based on various factors such as Maslow's hierarchy of needs (McDonald, Milne, \& Hong, 2002), social interaction and entertainment (Stewart et al., 2003), co-created value (Woratschek, Horbel, \& Popp, 2014), and demographics (James \& Ridinger, 2002). Stewart et al. (2003) argued that sports marketers need to choose marketing strategies to fit with the types of sports consumers. Hence, this study focused on the behaviour of consumers, which 
is related to the classification by McDonald et al. (2002) of the types of sports consumers into two groups: spectatorship and participation.

Extensive prior research has adopted the sports consumer typology of McDonald et al. (2002). Spectatorship is defined as people who invest their time in watching sports or reading articles related to sports (Trail \& James, 2001). Currently, there are many ways for spectators to view sports such as television, radio, websites, and competition at stadiums. Several studies (e.g., Bennett et al., 2009; Pritchard $\&$ Funk, 2006) have investigated the factors that affect spectatorship consumption. Pritchard and Funk (2006) have revealed that event attendance and sports media use increase the consumption behaviour of spectators by enhancing their sports experience. Kim and Trail (2010) argued that a lack of success and leisure alternatives provide negative effects on spectatorship consumption.

The second type of sports consumer is consumer communities or participation. Participation refers to people who join a competition at both the individual and team levels. Allender, Cowburn, and Foster (2006) explain participation as people who engage in physical and sports activities. Rohm, Milne, and McDonald (2006) suggest four types of participation: healthy athletes (physically and mentally oriented), social competitors (socialising nature of competition-oriented), actualised athletes (feeling of empowerment and achievement), and devotees (self-identification concept). Krein (2014) has defined nature or outdoor sports as activities where the participation consumers integrate the skills, human being, and natural world together, such as with surfing and mountaineering.

From the definition of sports consumers, Shoham and Kahle (1996) characterise participation as a consumption community and spectatorship as a communication community. These terms are categorised based on value perspective, which is related to the psychology and lifestyle of the consumer (Sun et al., 2004). Prensky and Wright-Isak (1997) argue that it is important to understand the social context when investigating value in the consumer behaviour domain. Community is a social institution that shares attitudes and behaviours within a group and influences individuals in society (Tajfel, 1982).

For these reasons, it can be implied that the psychological needs and lifestyles of the two types of sports consumers (spectatorship and participation) are different (McDonald et al., 2002) which may lead to different purchase intentions towards a sporting product. Additionally, the impact of each reference group (private vs. public vs. stranger) may provide diverse effects on purchase intentions for each type of sports consumer. Thus, this argument leads to the development of a framework and the hypotheses for this study. 


\section{RESEARCH HYPOTHESES AND THE THEORETICAL FRAMEWORK}

From a theoretical foundation and the related literature, it can be implied that reference groups influence sports consumers in various ways. Reference groups change the behaviour of consumers directly due to the pressure of the group's efforts to create standards for its members. To explain this phenomenon, the conceptual framework of this study is shown in Figures 1 and 2.

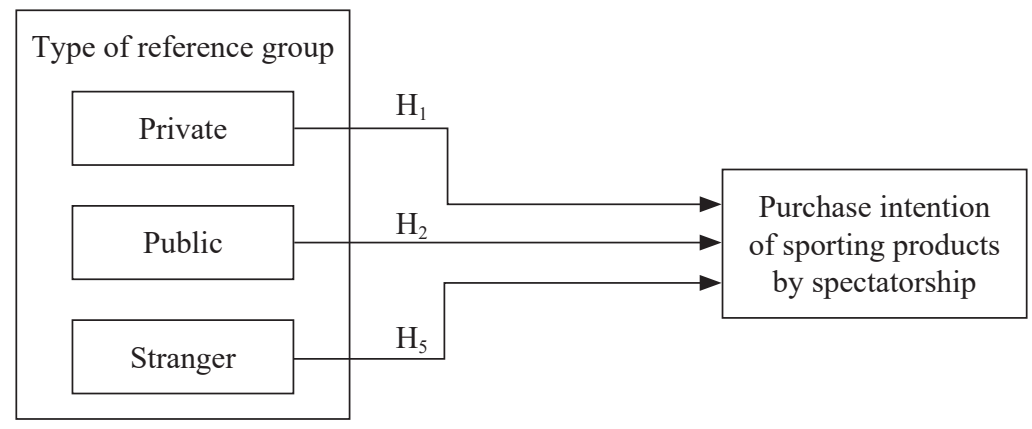

Figure 1. Conceptual model: Spectatorship consumer

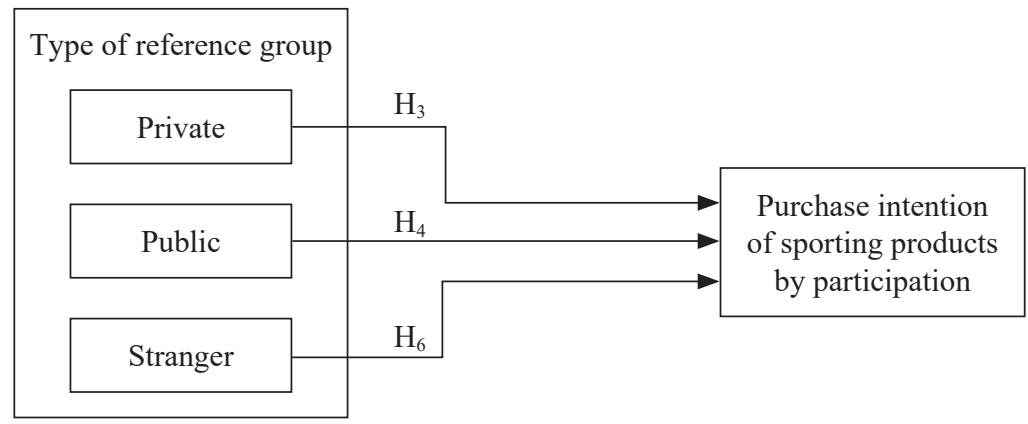

Figure 2. Conceptual model: Participation consumer

Spectators are people who spend their time following and watching sports (Trail \& James, 2001). The main members of the spectatorship group are spectators, viewers, and readers, but not athletes (Shoham \& Kahle, 1996; Sun et al., 2004). People are motivated to be interested in sports for many reasons, such as social, community, economic, and political (Ratten, 2016). The purchase intentions of a spectator towards a sporting product may not have been influenced by private groups. Based on the communication community proposed by Shoham and Kahle (1996), spectators are a group of consumers who share some communication tendencies. Spectators prefer to view sports or related activities via television, 
websites, or stadiums where they can see popular athletes, celebrities, and influencers, rather than engaging in sports competition or participating in sports activities. Moreover, spectators who attend the sport competition will benefit from psychological resources (e.g., positive mood, decreasing stress, and a feeling of achievement) and personal development (e.g., increasing motivation) (Inoue, Sato, Filo, Du, \& Funk, 2017). These benefits can engage spectators to become fans of teams or athletes. When spectators engage with teams or athletes, spectators try to find solidarity with teams or athletes by purchasing products related to the teams or athletes (Da Silva \& Las Casas, 2017).

From the discussion above, the reference groups that affect spectatorship are public groups including celebrities, experts, influencers, and well-known athletes. Spectators perceive the sporting product by watching sports and competitions, and mainly focus on famous athletes or sports experts. According to Morrison, Misener, and Mock (2018), they reveal that spectator sports generate spectacular revenue for the spectator sport industry. Then, we expect that spectators have an intention to purchase a sporting product influenced by the public groups, not the private group. It can be hypothesised that:

H1: The private group has no impact on the sporting product purchase intentions of spectators.

$\mathrm{H} 2$ : The public group positively influences the sporting product purchase intentions of spectators.

The second type of sports consumers are participation consumers, who love exercise of all types, including competitive sports, fitness sports, and naturerelated sports (Shoham \& Kahle, 1996; Sun et al., 2004). Today, a new type of participation is called fantasy sports. Fantasy sports participation concerns people who are primarily interested in online sport activities (Larkin, 2015). The reference group that may affect these participants is the private group, including family, friends, or close friends who exercise together. This reference group directly interacts with the consumers and informs the consumers about the sporting products during exercise or online activities. Trail, Anderson, and Fink (2000) suggest that social interaction motivates participants to join a group to exercise. This is because sports activities have been increasingly accepted in society (Sun et al., 2004), make life meaningful (Inoue et al., 2017), and express the self-image of the participants (Wang, Wann, Lu, \& Zhang, 2018). Participation includes the need for social acceptance in the group that the person belongs to (Cialdini \& Goldstein, 2004). As such, participants need to be recognised and immersed in their society in the real world (Escalas \& Bettman, 2005) through exercise with their group and online (Larkin, 2015) by interacting with others in their networks. 
However, participants have not been influenced by public groups. This is because participants pay little attention to or have little interest in watching sporting events or other entertainment (Sun et al., 2004). They focus on exercise by themselves or with friends and colleagues to improve their health or social status (Sun et al., 2004). Participants may not use sporting products that well-known athletes use or endorse but prefer to follow recommendations from their surroundings. It can be hypothesised that:

H3: The private group positively influences the sporting product purchase intentions of the participants.

H4: The public group has no impact on the sporting product purchase intentions of the participants.

Another type of reference group is strangers, but few studies have examined the impact of this group in the sports marketing domain. Consumers use information or guidelines from unknown persons before making decisions to purchase a sporting product. Scholars, such as Wen, Tan, and Chang (2009) revealed that strangers had a lesser influence on the consumers' purchasing decisions than close friends because strangers had weak ties to the consumer compared with other reference groups such as friends, family, and endorsers. Nevertheless, the impact of strangers on purchase intentions should be examined. The reason is that information is novel to consumers, although this information tends to be distrusted when there is less communication between the informants and receivers (Baker, Donthu, \& Kumar, 2016). This situation is called the "strength of weak ties" (Granovetter, 1983). According to McGrath and Otnes (1995), strangers have an impact on the purchase intentions of consumers. In the sports marketing domain, one expects that strangers may affect the sporting product purchase intentions (both participation and spectatorship), although strangers and sports consumers did not know or interact with each other before. Thus:

H5: Strangers positively influence the sporting product purchase intentions of the spectators.

H6: Strangers positively influence the sporting product purchase intentions of the participants.

\section{RESEARCH METHODOLOGY}

To investigate the effect of reference groups on purchase intentions for each type of sports consumer, this study includes experimental research. The population in this study consists of participants who had interest in either watching or playing 
sports. Next, participants who agreed to participate in this study were randomly assigned to one of two types of sports consumers: spectatorship and participation. Classifying the participants into two types of sports consumers is adapted from the work of Hoonsopon and Puriwat (2016). The participants were asked to read the instruction and message that reflected the sports consumer's characteristics before conducting the questionnaire. The instructions and messages embraced the ideas that "the key to the success of this research depends on whether [the participants] truly imagine [themselves] in these situations" (Luo, 2005, p. 290).

To increase the credibility of the findings, the content validity was examined to check the appropriateness of the measures by asking 4 academicians and 10 sports consumers to perform a review. After the measurement items were adjusted following the recommendations, they were pretested with 78 respondents to assess the understanding of the questions, manipulate the type of sports consumer, and acquire useful comments. After finishing the pre-test, the final questionnaire was sent to the respondents who agreed to participate in this study. The data were collected at sports stadiums and playgrounds. The total sample size was 701 . Questionnaires with missing data were deleted from the data analysis. Finally, a total of 593 usable questionnaires was obtained, consisting of 309 spectators and 284 participants ( $84.7 \%$ and $84.8 \%$ response rate, respectively). We used AMOS 22.0 to analyse the data.

This study adapted measurement items from past literature, as shown in the Appendix. A 5-point Likert-type scale was used as a measurement tool. For private and public groups, the measures were adopted from Serralvo et al. (2010), where 13 items were used to measure private groups and 9 questions were used to measure public groups. The stranger scale with four items was adapted from the definition of McGrath and Otnes (1995). Finally, the purchase intention construct was adapted from Hoonsopon (2016) and was measured by four items.

To enhance the reliability and validity of the findings, the study manipulated the two types of sports consumers (spectatorship and participation). In total, 78 respondents were randomly assigned to a type of sports consumer (34 respondents were assigned as spectators and 44 respondents were assigned as participants). Thirteen questions with a 7-point Likert scale, adapted from Sun et al. (2004), were used to classify the types of sports consumers. Before the participants began to answer the questionnaires, they were informed that there were no incorrect answers to reduce the effect of social desirability bias (Luo, 2005).

For spectatorship, the 34 respondents who were randomly assigned as spectators read the following message: "I spend my free time watching sports both at stadiums 
and through media such as TV and magazines. Additionally, I always talk with my friends about sports competitions. However, I dislike exercise". Six items were used to measure spectatorship: (1) I am interested and watch sports competitions regularly; (2) I always go to the stadium to watch sports competitions; (3) I follow sports competitions on various media, such as TV, radio, mobile phone, and newspapers; (4) I always check the results of sports competitions; (5) I always read sports magazines; and (6) I like to talk about sports with my friends.

For participation, the 44 respondents who were randomly assigned as participants read the following message: "I love to exercise. If I have free time, I always exercise alone or with my friends. Sometimes, I participate in sports competitions. However, I dislike watching sports". Participation is measured by five items: (1) I like to exercise regularly; (2) I like to attend sports competitions; (3) I like to exercise because I want to be healthy; (4) I like to exercise because I want to meet my friends and socialise; and (5) When I have free time, I always exercise.

Next, we manipulate the validity of the measure of the types of sports consumers. All of the participants answered 13 questions for all types of sports consumers. The results show that participants who were assigned to spectatorship had a higher spectatorship score than participants who were assigned to participation $\left(\overline{\mathrm{X}}_{\text {Spec }}=6.049\right.$ and $\left.\overline{\mathrm{X}}_{\text {Par }}=3.288 ; \mathrm{t}_{(76)}=8.947, p<0.00\right)$. In the same way, participants who were assigned to participation had a higher participant score than participants who were assigned to spectatorship $\left(\overline{\mathrm{X}}_{\mathrm{Par}}=5.198\right.$ and $\overline{\mathrm{X}}_{\mathrm{Spec}}=2.504 ; \mathrm{t}_{(76)}=8.584$, $p<0.00$ ). Therefore, it can be summarised that participants can reflect their own sports consumer characteristics.

To evaluate the reliability and validity of the measure in a proposed model, we followed the guidelines of Hair, Anderson, Babin, and Black (2010), and Memon, Salleh, and Baharom (2016). To assess the reliability of constructs in a conceptual model, Cronbach's alpha $(\alpha)$ was used. Cronbach (1951) revealed that an $\alpha$ statistic above 0.7 indicated internally consistent reliability. The findings showed that the $\alpha$ for all constructs in the spectatorship group ranged from 0.875 to 0.929 , suggesting a strong reliability. Similarly, for the participation group, the $\alpha$ value for all constructs was greater than 0.7 , which showed the reliability of the constructs. Additionally, the composite reliability of all constructs was higher than 0.7 , which showed good reliability (Nunnally, 1978). Moreover, composite reliability (CR) was used to test the reliability of constructs. Hair et al. (2010) suggested that the cut-off CR value should be 0.7 or above when assessing reliability. The findings showed that all constructs have a CR higher than 0.7 , which provided good reliability. 
To evaluate the validity of the measure, confirmatory factor analysis is used. For the spectatorship group, we assess convergent validity. Hair et al. (2010) suggest that the standardised factor loading $(\lambda)$ of each item should be 0.5 or higher, and preferably 0.7 . The findings show that 18 of 20 items have standardised factor loadings higher than 0.7 , which reveals a good convergent validity. Standardised factor loadings are shown in the Appendix. Additionally, Fornell and Larcker (1981) suggest that the average variance extracted (AVE) should be greater than 0.5 to reveal the convergent validity. The results show that all constructs have an AVE higher than 0.5 . Next, discriminant validity is examined. We use the chisquare difference test for all constructs (six-paired tests). The findings show that all pairs have a significant difference (for example, the test of PRI and PUB: $\Delta \chi 2$ [1] $=54.334, p<0.01$ ), verifying the discriminant validity (Anderson \& Gerbing, 1988). Last, the construct validity is assessed. Browne and Cudeck (1993) recommend that an approximate value of 0.08 or less for the Root Mean Square Error of Approximation (RMSEA) provides an acceptable error of approximation. Further, a value of the fit indices, such as comparative fit index (CFI), incremental fit index (IFI), and normed fit index (NFI), greater than 0.9 means a satisfactory fit to the data (Bentler \& Bonett, 1980). The results reveal an adequate fit between the model data and the suggested values $(\chi 2[143]=283.669, p<0.01$; $\chi 2 /$ d.f. $=1.984 ;$ RMSEA $=0.057$; CFI $=0.963 ; \mathrm{IFI}=0.964 ; \mathrm{NFI}=0.929$ ). In summary, the measurement of spectatorship consumers shows reliability and validity.

Next, to assess the validity of the measurement of the participation group, the results demonstrate that 18 of 20 items have standardised factor loadings higher than 0.7, which reveals a good convergent validity. The standardised factor loadings are shown in the Appendix. Additionally, the findings reveal that all constructs provide AVEs higher than 0.5, revealing the convergent validity. Next, the discriminant validity is explored. The findings show that all pairs have a significant difference (for example, the test of PRI and PUB: $\Delta \chi 2[1]=84.559, p<0.01$ ), verifying the discriminant validity. Last, the construct validity is examined. The findings provide an adequate fit between the model data and the suggested values $(\chi 2[140]$ $=278.057, p<0.01 ; \chi 2 /$ d.f. $=1.986 ;$ RMSEA $=0.059 ;$ CFI $=0.960 ;$ IFI $=0.960$; $\mathrm{NFI}=0.923$ ). In summary, the measurement of spectatorship consumers shows reliability and validity. Descriptive statistics of the spectatorship and participation groups are shown in Tables 1 and 2. 
Table 1

Descriptive statistics: Spectatorship group

\begin{tabular}{lllll}
\hline & PUR & PRI & PUB & STR \\
\hline PUR & 0.875 & & & \\
PRI & $0.336^{* *}$ & 0.895 & & \\
PUB & $0.350^{* *}$ & $0.488^{* *}$ & 0.929 & \\
STR & $0.208^{* *}$ & $0.252^{* *}$ & 0.071 & 0.875 \\
\hline Mean & 3.341 & 3.132 & 3.518 & 2.266 \\
SD & 0.850 & 0.841 & 0.899 & 0.815 \\
CR & 0.876 & 0.896 & 0.930 & 0.880 \\
AVE & 0.639 & 0.593 & 0.727 & 0.648 \\
\hline
\end{tabular}

Note: $\mathrm{PUR}=$ purchase intention; $\mathrm{PRI}=$ private group; $\mathrm{PUB}=$ public group; $\mathrm{STR}=$ stranger group; $\mathrm{CR}=$ composite reliability; AVE = average variance extracted ${ }^{* *} p<0.01$; Cronbach's alpha is shown in diagonal

Table 2

Descriptive statistics: Participation group

\begin{tabular}{lclll}
\hline & PUR & PRI & PUB & STR \\
\hline PUR & 0.822 & & & \\
PRI & $0.140^{*}$ & 0.890 & & \\
PUB & 0.051 & $0.335^{* *}$ & 0.941 & \\
STR & $-0.192^{* *}$ & $0.222^{* *}$ & $0.267^{* *}$ & 0.868 \\
\hline Mean & 3.856 & 2.926 & 2.520 & 2.286 \\
SD & 0.603 & 0.782 & 0.880 & 0.750 \\
CR & 0.829 & 0.889 & 0.938 & 0.857 \\
AVE & 0.553 & 0.576 & 0.754 & 0.602 \\
\hline
\end{tabular}

Note: ${ }^{*} p<0.05 ;{ }^{* *} p<0.01$; Cronbach's alpha is shown in diagonal

\section{RESULTS}

To investigate the effect of private groups, public groups, and strangers on sporting product purchase intentions, these relationships were tested using structural equation modelling (SEM). The analysis was separated into two groups: respondents who were assigned as spectators and those assigned as participants. The results are shown in Table 3. 
For spectatorship, we proposed that private groups cannot motivate the sporting product purchase intentions of spectators, as in $\mathrm{H} 1$. The results showed a congruence with the proposed hypothesis $\left(\beta_{1}=0.112, p>0.1\right)$. Nevertheless, private groups had a positive effect on the sporting product purchase intentions of the spectators $\left(\beta_{2}=0.392, p<0.01\right)$. Thus, $\mathrm{H} 2$ is supported. For H5, we suggested that strangers positively influence the sporting product purchase intentions of spectators. The findings showed that this hypothesis was statistically significant $\left(\beta_{5}=0.198\right.$, $p<0.01$ ), which confirms H5.

For participation, we proposed that private groups influence the sporting product purchase intentions of the participants, as in $\mathrm{H} 3$. The findings revealed that $\left(\beta_{3}=0.133, p<0.051\right)$, confirming H3. Consistent with H4, the results revealed that public groups had no impact on the sporting product purchase intentions of the participants $\left(\beta_{4}=0.034, p>0.1\right)$. Hence, $\mathrm{H} 4$ is supported. Last, the results revealed that strangers reduce the participants' intentions to purchase sporting good products $\left(\beta_{6}=-0.312, p<0.01\right)$. Hence, H6 is not supported. A possible explanation might be that participants may be familiar with sporting products and brands. Participants have real experience from using sporting products when they exercise and talk with their friends. As a result, participants have been influenced by themselves and their friends more than by influencers and strangers.

Table 3

Results of the influence of reference groups on sports consumers' purchase intentions

\begin{tabular}{llc}
\hline \multirow{2}{*}{ Independent variables } & \multicolumn{2}{c}{ Dependent variables } \\
\cline { 2 - 3 } & \multicolumn{1}{c}{ PUR $_{\text {Spec }}$} & \multicolumn{1}{c}{ PUR $_{\text {Par }}$} \\
\hline PRI (H1 and H3) & $0.112(1.782)$ & $0.133(2.547)^{*}$ \\
PUB (H2 and H4) & $0.392(4.886)^{* *}$ & $0.034(0.601)$ \\
STR (H5 and H6) & $0.198(3.010)^{* *}$ & $-0.312(-4.869)^{* *}$ \\
$\mathrm{R}^{2}$ & 0.161 & 0.161 \\
\hline
\end{tabular}

Note: PUR $_{\mathrm{Spec}}$ spectators' purchase intentions; $\mathrm{PUR}_{\mathrm{Par}}=$ participants' purchase intentions; the number in parentheses is the t-value

\section{CONCLUSION}

The significant growth of the sports industry has led a number of marketing scholars and practitioners to focus on this industry. Many scholars explored numerous factors that impacted the purchase intention of sports consumers. This study expanded the existing knowledge about sports consumers' decisions to purchase by 
clarifying the role of reference groups (private, public, and strangers) on sporting product purchase intentions for each type of sports consumer (spectatorship and participation). The study found that reference groups had an impact on the purchase intentions of sports consumers. However, the effect of reference groups on the purchase intentions of sports consumers varied. Our study provides several contributions, as follows.

First, this research extended the social identity theory and the concept of reference groups to the sports industry. Social identity theory explains how the behaviour of individuals varies based on the influence of reference groups. We find that reference groups influenced the behaviour of individuals in terms of sporting product purchase intentions. However, the effect of reference groups varies depending on each individual's relative position in society. As a result, scholars adapt the role of reference groups to the sports marketing domain, including the identity of athletes (Underwood et al., 2001), social media to advertise sporting products (Filo et al., 2015), and word-of-mouth strategies (Swanson et al., 2003) to fit the norm of the firm's target customers (spectatorship and participation).

Second, our findings explain how to motivate each type of sports consumer (spectatorship and participation) to purchase sporting products by using reference groups. This is because the characteristics of sports consumers are not the same. Shoham and Kahle (1996) define participation as a consumption community, and spectatorship as a communication community. Additionally, there is earlier research examining the effect of strangers on the behaviour of sports consumers. According to Childers and Rao (1992), there are several types of reference groups, and each type of reference group has a diverse effect on individuals. Spectators are motivated to purchase sporting products when they acquire information from public groups, such as reputable athletes or celebrities who use or recommend the sporting product. Furthermore, strangers can enhance sporting product purchase intentions through the strength of the weak ties effect, which states that consumers believe that information from unknown persons is novel (Granovetter, 1983). Nevertheless, friends cannot arouse spectators to buy sporting products. For participants, sporting product purchase intentions can be enhanced if participants use private groups (e.g., friends) as guidelines when they make purchasing decisions about sporting products. Participants need to be immersed in society by joining the group to exercise. This situation increases the chances that they will buy sporting products following the recommendations of their friend or group. However, influencers, celebrities, and strangers cannot persuade participants to purchase sporting products. In summary, public groups and strangers influence the behaviour of spectators, but public groups influence the behaviour of participants. 
Our findings also provide managerial implications. First, sports marketing managers can adopt the study findings to enhance the sporting product purchase intentions of customers. Managers who use an appropriate reference group strategy to fit with the different types of sports consumers will increase the sales rate of their sporting products. If a firm desire to increase the likelihood of purchase by the spectators who like to watch sports competitions, then using influencers such as well-known athletes or celebrities who are related to sports is the effective method. Managers can also launch media campaigns using celebrity endorsers, which involves the celebrities using a firm's sporting products or services. On the other hand, to increase the sporting product purchase intentions of participants who like to exercise or play sports, managers should use private groups, such as friends or family, to persuade participants to make a purchase.

Second, strategies such as word-of-mouth or refer-a-friend marketing campaigns are appropriate strategies to boost the intention to purchase of the participants by sharing brand values (functional, emotional, and social value) or customer experiences with sporting products. Additionally, managers can motivate participants to purchase sporting products by using strangers. Managers can promote strangers who provide novel information or related experiences with sporting products to spectators. Nevertheless, managers should not use strangers to stimulate the sporting product purchase intentions of participants.

\section{Limitations and Directions of Future Research}

Although the findings contribute to the existing literature by providing the effects of reference groups on the purchase intentions related to a sports brand for each type of sports consumer, several limitations should be considered. First, some sports consumers may watch and play sports at the same time, which increases the obstacles to clarifying the type of sports consumer they are and makes it difficult to interpret the findings. Future research should examine in detail the behaviour of sports consumers who play and watch sports. Second, this study collected crosssectional data, which cannot confirm the causal effect of reference groups and the purchase intentions towards sporting products. Future research should gather longitudinal data to test the causal effect of the conceptual framework. Third, are spectators who watch sports online affected by reference groups in the same way as those who watch them at the stadium? A future study should compare the effect of media types on sports consumers and their purchase intentions. Fourth, it would be interesting to investigate the types of sports consumers in terms of moderating effects. This effect can offer more insightful results for comparing the magnitude of the relationship between reference groups and purchase intentions 
for each type of sports consumer. Fifth, e-sports play a significant role in the present day, especially for consumers in generations $\mathrm{Y}$ and Z. It is possible that e-sports have an impact on the purchase intentions of spectators and participants. Future research should examine the role of e-sports on the purchase intentions of sports consumers. Finally, sports companies today launch innovative products and services to the market constantly. Future research should examine how the spectator and participant adopt new products or services (Pitchayadol, Hoonsopon, Chandrachai, \& Triukose, 2018). It is hoped that our findings can increase the interest in this research domain.

\section{APPENDIX}

\section{Measurement Scale}

\begin{tabular}{|c|c|c|}
\hline & $\lambda_{\text {Spec }}$ & $\lambda_{\text {Par }}$ \\
\hline \multicolumn{3}{|l|}{ Private Group (PRI) } \\
\hline \multicolumn{3}{|l|}{ I consult with my family before deciding to purchase sporting product. ${ }^{* *}$} \\
\hline \multicolumn{3}{|l|}{ It is important that our family use sporting product like me.** } \\
\hline \multicolumn{3}{|l|}{ I always buy same sporting product brand with my family. ${ }^{* *}$} \\
\hline I always ask my friends about sporting product that I want to buy. & 0.575 & 0.575 \\
\hline $\begin{array}{l}\text { If I know what is the favourite sporting product brand of my friends, } \\
\text { I will buy that sporting product. }\end{array}$ & 0.729 & 0.737 \\
\hline It is important that others like the sporting product which I have. & 0.782 & 0.778 \\
\hline I buy the same sporting product as the others. & 0.813 & 0.819 \\
\hline $\begin{array}{l}\text { I feel I have same identity with my friends when I use same sporting } \\
\text { product brand with them. }\end{array}$ & 0.813 & 0.802 \\
\hline My friends have influenced with me when I purchase sporting product. & 0.857 & 0.859 \\
\hline \multicolumn{3}{|l|}{ Public Group (PUB) } \\
\hline Frequently, I look sporting product brand that influencers use that brand. & 0.849 & 0.852 \\
\hline I buy sporting product which make me like influencers. & 0.836 & 0.838 \\
\hline I buy sporting product following with well-known athletes. & 0.920 & 0.919 \\
\hline $\begin{array}{l}\text { My confidence increases when I buy same sporting product brand with } \\
\text { influencers. }\end{array}$ & 0.899 & 0.896 \\
\hline I search information about sporting product from well-known athletes. & 0.749 & 0.752 \\
\hline
\end{tabular}


Appendix (continued)

\begin{tabular}{lcc}
\hline & $\lambda_{\text {Spec }}$ & $\lambda_{\text {Par }}$ \\
\hline $\begin{array}{l}\text { Stranger (STR) } \\
\text { While I choose sporting product in store, I always buy that sporting }\end{array}$ & 0.888 & 0.891 \\
product following unknown persons. & & \\
$\begin{array}{l}\text { I buy sporting product same with unknown persons because I believe } \\
\text { with them. }\end{array}$ & 0.805 & 0.809 \\
I remember sporting product that unknown persons use. & 0.669 & 0.674 \\
I always buy sporting product same with unknown persons. & 0.800 & 0.803 \\
Purchase Intention on Sporting Product (PUR) & & \\
I interest to buy sporting product. & 0.898 & 0.893 \\
I seriously consider before buying sporting product. & 0.821 & 0.814 \\
I will recommend sporting product that I regularly use to my friends. & 0.800 & 0.792 \\
It is possible for me to buy sporting product. & 0.737 & 0.728 \\
\hline
\end{tabular}

Note: ${ }^{* *}$ Item is deleted from further analysis

\section{REFERENCES}

Abrams, D., \& Hogg, M.A. (1988). Comments on the motivational status of self-esteem in social identity and intergroup discrimination. European Journal of Social Psychology, 18(4), 317-334. https://doi.org/10.1002/ejsp.2420180403

Allender, S., Cowburn, G., \& Foster, C. (2006). Understanding participation in sport and physical activity among children and adults: A review of qualitative studies. Health Education Research, 21(6), 826-835. https://doi.org/10.1093/her/cyl063

Anderson, J.C., \& Gerbing, D.W. (1988). Structural equation modeling in practice: A review and recommended two-step approach. Psychological Bulletin, 103(3), 411-423. https://doi.org/10.1037//0033-2909.103.3.411

Baker, A.M., Donthu, N., \& Kumar, V. (2016). Investigating how word-of-mouth conversations about brands influence purchase and retransmission intentions. Journal of Marketing Research, 53(2), 225-239. https://doi.org/10.1509/ jmr.14.0099

Bearden, W.O., \& Etzel, M.J. (1982). Reference group influence on product and brand purchase decisions. Journal of Consumer Research, 9(2), 183-194. https://doi. org/10.1086/208911

Bearden, W.O., Netemeyer, R.G., \& Teel, J.E. (1989). Measurement of consumer susceptibility to interpersonal influence. Journal of Consumer Research, 15(4), 473-481.

Belk, R.W. (1988). Possessions and the extended self. Journal of Consumer Research, 15(2), 139-168. 
Bennett, G., Ferreira, M., Lee, J., \& Polite, F. (2009). The role of involvement in sports and sport spectatorship in sponsor's brand use: The case of Mountain Dew and action sports sponsorship. Sport Marketing Quarterly, 18(1), 14-24.

Bentler, P.M., \& Bonett, D.G. (1980). Significance tests and goodness of fit in the analysis of covariance structures. Psychological Bulletin, 88(3), 588-606. https://doi. org/10.1037/0033-2909.88.3.588

Bodet, G., \& Bernache-Assollant, I. (2011). Consumer loyalty in sport spectatorship services: The relationships with consumer satisfaction and team identification. Psychology \& Marketing, 28(8), 781-802. https://doi.org/10.1002/mar.20412

Browne, M., \& Cudeck, R. (1993). Alternative ways of assessing model fit. In K.A. Bollen, \& J.S. Long (Eds.), Testing structural equation models (pp. 136-162). Newbury Park, CA: Sage.

Burnett, J., Menon, A., \& Smart, D.T. (1993). Sports marketing: A new ball game with new rules. Journal of Advertising Research, 33(5), 21-36.

Childers, T.L., \& Rao, A.R. (1992). The influence of familial and peer-based reference groups on consumer decisions. Journal of Consumer Research, 19(2), 198-211. https://doi.org/10.1086/209296

Cialdini, R.B., \& Goldstein, N.J. (2004). Social influence: Compliance and conformity. Annual Review of Psychology, 55, 591-621. https://doi.org/10.1146/annurev. psych.55.090902.142015

Cronbach, L.J. (1951). Coefficient alpha and the internal structure of tests. Psychometrika, 16(3), 297-334. https://doi.org/10.1007/bf02310555

Da Silva, E.C., \& Las Casas, A.L. (2017). Sport fans as consumers: An approach to sport marketing. British Journal of Marketing Studies, 5(4), 36-48.

Drayer, J., Shapiro, S.L., Dwyer, B., Morse, A.L., \& White, J. (2010). The effects of fantasy football participation on NFL consumption: A qualitative analysis. Sport Management Review, 13(2), 129-141. https://doi.org/10.1016/j.smr.2009.02.001

Escalas, J.E., \& Bettman, J.R. (2005). Self-construal, reference groups, and brand meaning. Journal of Consumer Research, 32(3), 378-389. https://doi.org/10.1086/497549

Farrell, A., Fink, J.S., \& Fields, S. (2011). Women's sport spectatorship: An exploration of men's influence. Journal of Sport Management, 25(3), 190-201. https://doi. org/10.1123/jsm.25.3.190

Ferreira, R.R. (1997). The effect of private club members' characteristics on the identification level of members. Journal of Hospitality \& Leisure Marketing, 4(3), 41-62. https://doi.org/10.1300/j150v04n03_04

Filo, K., Lock, D., \& Karg, A. (2015). Sport and social media research: A review. Sport Management Review, 18(2), 166-181. https://doi.org/10.1016/j.smr.2014.11.001

Fornell, C., \& Larcker, D.F. (1981). Structural equation models with unobservable variables and measurement error: Algebra and statistics. Journal of Marketing Research, 18(3), 382-388. https://doi.org/10.1177/002224378101800313

Granovetter, M. (1983). The strength of weak ties: A network theory revisited. Sociological Theory, 1(6), 201-233. https://doi.org/10.2307/202051

Hair, J.F., Anderson, R.E., Babin, B.J., \& Black W.C. (2010). Multivariate data analysis: A global perspective. Upper Saddle River, NJ: Pearson. 
Hoonsopon, D. (2016). Accelerating adoption of new products of Thai consumers: The moderating roles of self-brand concept and reference group. Journal of AsiaPacific Business, 17(2), 151-172. https://doi.org/10.1080/10599231.2016.11660 23

Hoonsopon, D., \& Puriwat, W. (2016). The effect of reference groups on purchase intention: Evidence in distinct types of shoppers and product involvement. Australasian Marketing Journal, 24(2), 157-164. https://doi.org/10.1016/j.ausmj.2016.05.001

Hoyer, W.D., MacInnis, D.J., \& Pieters, R. (2001). Customer behavior. Boston, MA: Houghton Mifflin Company.

Inoue, Y., Sato, M., Filo, K., Du, J., \& Funk, D.C. (2017). Sport spectatorship and life satisfaction: A multicountry investigation. Journal of Sport Management, 31(4), 419-432. https://doi.org/10.1123/jsm.2016-0295

James, J.D., \& Ridinger, L.L. (2002). Female and male sport fans: A comparison of sport consumption motives. Journal of Sport Behavior, 25(3), 260-278.

Kim, Y.K., \& Trail, G. (2010). Constraints and motivators: A new model to explain sport consumer behavior. Journal of Sport Management, 24(2), 190-210. https://doi. org/10.1123/jsm.24.2.190

Krein, K.J. (2014). Nature sports. Journal of the Philosophy of Sport, 41(2), 193-208.

Kurpis, L.H.V., Bozman, C.S., \& Kahle, L.R. (2010). Distinguishing between amateur sport participants and spectators: The list of values approach. International Journal of Sport Management and Marketing, 7(3-4), 190-201. https://doi.org/10.1504/ ijsmm.2010.032550

Kurt, D., Inman, J.J., \& Argo, J.J. (2011). The influence of friends on consumer spending: The role of agency-communion orientation and self-monitoring. Journal of Marketing Research, 48(4), 741-754. https://doi.org/10.1509/jmkr.48.4.741

Larkin, B. (2015). An examination of fantasy sport participation motives and substitution versus attendance intention. Sport Marketing Quarterly, 24(2), 120-133.

Luo, X. (2005). How does shopping with others influence impulsive purchasing? Journal of Consumer Psychology, 15(4), 288-294. https://doi.org/10.1207/ s15327663jcp1504_3

Madrigal, R. (2000). The influence of social alliances with sports teams on intentions to purchase corporate sponsors' products. Journal of Advertising, 29(4), 13-24. https://doi.org/10.1080/00913367.2000.10673621

Marsh, H.W., Balla, J.R., \& Hau, K.-T. (1996) An evaluation of incremental fit indices: A clarification of mathematical and empirical properties. In G.A. Marcoulides, \& R.E. Schumacker (Eds.), Advanced structural equation modeling techniques (pp. 315-353). Mahwah, NJ: Lawrence Erlbaum.

McDonald, M.A., Milne, G.R., \& Hong, J. (2002). Motivational factors for evaluating sport spectator and participant markets. Sport Marketing Quarterly, 11(2), 100-113.

McGrath, M.A., \& Otnes, C. (1995). Unacquainted influencers: When strangers interact in the retail setting. Journal of Business Research, 32(3), 261-272. https://doi. org/10.1016/0148-2963(94)00051-f 
Memon, M.A., Salleh, R., \& Baharom, M.N.R. (2016). The link between training satisfaction, work engagement and turnover intention. European Journal of Training and Development, 40(6), 407-429. https://doi.org/10.1108/ejtd-102015-0077

Morrison, K.A., Misener, K.E., \& Mock, S.E. (2018). The influence of corporate social responsibility and team identification on spectator behavior in major junior hockey. Leisure Sciences, 40(1-2), 1-19. https://doi.org/10.1080/01490400.201 7.1408511

Mullin, B., Hardy, S., \& Sutton, W. (2000). Sport marketing (2nd ed.). Champaign, IL: Human Kinetics.

Noguti, V., \& Russell, C.A. (2014). Normative influences on product placement effects: Alcohol brands in television series and the influence of presumed influence. Journal of Advertising, 43(1), 46-62. https://doi.org/10.1080/00913367.2013.81 0557

Nunnally, J., (1978). Psychometric theory. Auflage, NY: McGraw-Hill.

Pitchayadol, P., Hoonsopon, D., Chandrachai, A., \& Triukose, S. (2018). Innovativeness in Thai family SMEs: An exploratory case study. Journal of Small Business Strategy, 28(1), 38-48.

Prensky, D., \& Wright-Isak, C. (1997). Advertising, values and the consumption community. In L.R. Kahle, \& L. Chiagouris (Eds.), Values, lifestyles and psychographics (pp. 69-81). Philadelphia, PA: Taylor \& Francis Inc.

Pritchard, M.P., \& Funk, D.C. (2006). Symbiosis and substitution in spectator sport. Journal of Sport Management, 20(3), 299-321. https://doi.org/10.1123/jsm.20.3.299

Ratten, V. (2016). The dynamics of sport marketing: Suggestions for marketing intelligence and planning. Marketing Intelligence \& Planning, 34(2), 162-168. https://doi. org/10.1108/mip-07-2015-0131

Rohm, A.J., Milne, G.R., \& McDonald, M. (2006). A mixed-method approach for developing market segmentation typologies in the sports industry. Sport Marketing Quarterly, 15(1), 29-39.

Serralvo, F., Sastre, P., \& Joao, B. (2010). Reference group influence on consumer decision making process: A study in the Brazilian sports utilitarian vehicles segment. Journal of Academy of Business and Economics, 10(2), 157-161.

Shirazi, A., Lorestani, H.Z., \& Mazidi, A.K. (2013). Investigating the effects of brand identity on customer loyalty from social identity perspective. Iranian Journal of Management Studies, 6(2), 153-178.

Shoham, A., \& Kahle, L. (1996). Spectators, viewers, readers: Communication and consumption communities in sport marketing. Sport Marketing Quarterly, 5, $11-20$.

Statista. (2018). Retrieved from https://www.statista.com/statistics/370560/worldwidesports-market-revenue

Stewart, B., Smith, A., \& Nicholson, M. (2003). Sport consumer typologies: A critical review. Sport Marketing Quarterly, 12(4), 206-216. 
Sun, T., Youn, S., \& Wells, W.D. (2004). Exploration of consumption and communication communities in sports marketing. In L.R. Kahle, \& C. Riley (Eds.), Sports marketing and the psychology of marketing communication (pp. 3-26). London, UK: Psychology Press. https://doi.org/10.4324/9781410610003

Swanson, S.R., Gwinner, K., Larson, B.V., \& Janda, S. (2003). Motivations of college student game attendance and word-of-mouth behavior: The impact of gender differences. Sport Marketing Quarterly, 12(3), 151-162.

Tajfel, H. (1982). Social psychology of intergroup relations. Annual Review of Psychology, 33(1), 1-39.

Tan, S.J. (1999). Strategies for reducing consumers' risk aversion in Internet shopping. Journal of Consumer Marketing, 16(2), 163-180. https://doi. org/10.1108/07363769910260515

Till, B.D., \& Shimp, T.A. (1998). Endorsers in advertising: The case of negative celebrity information. Journal of Advertising, 27(1), 67-82. https://doi.org/10.1080/00913 367.1998.10673543

Tingchi Liu, M., Huang, Y.-Y., \& Minghua, J. (2007). Relations among attractiveness of endorsers, match-up, and purchase intention in sport marketing in China. Journal of Consumer Marketing, 24(6), 358-365. https://doi. org/10.1108/07363760710822945

Trail, G.T., Anderson, D.F., \& Fink, J.S. (2000). A theoretical model of sport spectator consumption behavior. International Journal of Sport Management, 1(3), 154180.

Trail, G.T., \& James, J.D. (2001). The motivation scale for sport consumption: Assessment of the scale's psychometric properties. Journal of Sport Behavior, 24(1), 108-127.

Underwood, R., Bond, E., \& Baer, R. (2001). Building service brands via social identity: Lessons from the sports marketplace. Journal of Marketing Theory and Practice, 9(1), 1-13. https://doi.org/10.1080/10696679.2001.11501881

Van Leeuwen, L., Quick, S., \& Daniel, K. (2002). The sport spectator satisfaction model: A conceptual framework for understanding the satisfaction of spectators. Sport Management Review, 5(2), 99-128. https://doi.org/10.1016/s14413523(02)70063-6

Venkatesan, M. (1966). Experimental study of consumer behavior conformity and independence. Journal of Marketing Research, 3(4), 384-387. https://doi. org/10.1177/002224376600300407

Wang, J.J., Wann, D.L., Lu, Z., \& Zhang, J.J. (2018). Self-expression through sport participation: Exploring participant desired self-image. European Sport Management Quarterly, 18(5), 583-606. https://doi.org/10.1080/16184742.201 8.1446994

Watkins, B.A. (2014). Revisiting the social identity-brand equity model: An application to professional sports. Journal of Sport Management, 28(4), 471-480. https://doi. org/10.1123/jsm.2013-0253 
Wen, C., Tan, B.C., \& Chang, K.T.-T. (2009). Advertising effectiveness on social network sites: An investigation of tie strength, endorser expertise and product type on consumer purchase intention. Proceedings of the International Conference on Information Systems, ICIS 2009, Phoenix, Arizona, USA, December 15-18, p. 151.

Woratschek, H., Horbel, C., \& Popp, B. (2014). The sport value framework: A new fundamental logic for analyses in sport management. European Sport Management Quarterly, 14(1), 6-24. https://doi.org/10.1080/16184742.2013.865776

Zhou, Y., \& Tainsky, S. (2017). Enhanced brand credibility of American athletes with international teammates. Sport Marketing Quarterly, 26(2), 63-74. 